\title{
The Fed's Response to the Credit Crunch
}

\section{Craig P. Aubuchon, Senior Research Associate}

\begin{abstract}
"In unusual and exigent circumstances, the Board of Governors of the Federal Reserve System...may authorize any Federal reserve bank...to discount for any individual, partnership, or corporation, notes, drafts, and bills of exchange when such notes, drafts, and bills of exchange are indorsed or otherwise secured to the satisfaction of the Federal reserve bank: Provided...that such individual, partnership, or corporation is unable to secure adequate credit accommodations from other banking institutions."
\end{abstract}

—Federal Reserve Act \$13(3)

$\mathrm{U}$ S. house prices peaked in April 2007, as measured by the Federal Housing Finance Agency's PurchaseOnly House Price Index. As U.S. house prices flattened, and then declined, U.S. financial institutions exposed to mortgages and mortgage-related investments began to experience financial distress. By August 2007, the Federal Open Market Committee acknowledged the growing credit stress, noting that, "In current circumstances, depository institutions may experience unusual funding needs because of dislocations in money and credit markets."

Since then, the strain in credit markets has intensified. Under normal conditions, banks borrow and lend money to individuals and institutions. However, with the current economic environment, banks, institutions, and individuals are unsure of each other's ability to repay a loan or investment. This risk manifests itself in both higher interest rates (the cost of borrowing money) and tighter lending standards. Economists and policymakers often gauge the severity of credit stress by the spread between the London Interbank Overnight Rate (LIBOR) and the federal funds rate. LIBOR is the interest rate that banks charge on loans to one another; the federal funds rate is the interest rate on loans of surplus reserves at Federal Reserve Banks. Under normal conditions, these rates are similar; but at times during the past year, the overnight LIBOR has been much higher than the federal funds rate because of perceived increased credit risk in financial markets. When interbank interest rates rise and banks tighten lending standards, individuals and businesses find it more difficult and costly to borrow for both personal consumption and business development.

\section{Federal Reserve Actions}

The Federal Reserve Board has used Section 13(3) of the Federal Reserve Act to create several new lending facilities to address the ongoing strains in the credit market. These facilities have complemented traditional policy actions undertaken during the same period. Section 13(3) requires that banks be "unable to secure adequate credit" from other sources. Thus, the Fed is considered the "lender of last resort." Since August 2007, the Fed has addressed credit distress in three ways: by extending the duration of loans, increasing acceptable collateral, and extending the reach of lending beyond primary dealers.

\section{The Initial Expansion: Extending the Duration of Loans}

On August 17, 2007, the Fed increased the borrowing term on primary credit to 30 days, well beyond the traditional overnight discount window loan. Then, on December 12, 2007, the Fed introduced the Term Auction Facility (TAF) also to provide funds for a longer durationfor terms of 28 and 84 days. The TAF allows interested depository institutions to participate in an auction-the lowest bid that allocates all available funds becomes the interest rate on the loan for all borrowers. As of December 31, 2008, $\$ 450.2$ billion in term auction credit was outstanding on the Fed's balance sheet.

\section{The Second Expansion: Increasing Acceptable Collateral}

On March 11, 2008, the Fed initiated the second type of new lending by expanding acceptable collateral through the Term Securities Lending Facility (TSLF). The TSLF makes funds available at 28-day maturity and accepts as collateral a wide range of residential mortgage-backed securities. Another expansion of collateral, the Primary Dealer Credit Facility (PDCF), was established on March 16. The PDCF provides overnight financing similar to the discount window, but accepts any assets deemed to be collateral by other major clearing banks. Most recently, on 
November 25, 2008, the Fed again expanded the definition of acceptable collateral under the Term Asset-Backed Securities Lending Facility (TALF), which accepts highly rated assets backed by student loans, auto loans, credit card loans, and loans guaranteed by small businesses. One goal of this program is to help support the market for these assets and lower interest rate spreads for consumers and small businesses.

\section{"The Federal Reserve Board has used Section 13(3) of the Federal Reserve Act to create several new lending facilities to address the ongoing strains in the credit market."}

\section{The Third Expansion:}

\section{Extending the Reach of Lending Facilities}

The Fed introduced the third expansion of lending in September 2008. Following the bankruptcy of Lehman Brothers on September 15, credit conditions deteriorated further, particularly in the markets for short-term financing by corporations. Often, businesses issue commercial paper to fund their operations, such as payroll obligations. Money market mutual funds play a major role in this market, purchasing commercial paper from creditworthy companies and using the interest payments on the commercial paper to provide a steady rate of return. By late September, the perception of increased risk caused money market funds to reduce their purchases of commercial paper, which left many corporations unable to finance their operations. To address these liquidity concerns, the Fed created three programs to extend the scope of its lending beyond primary dealers.
The first facility, known as the AMLF, 2 allows money market mutual funds to sell commercial paper to banks and then allows those banks to post the commercial paper as collateral for loans from the Fed. This guaranteed market allows banks and money market mutual funds to confidently trade in commercial paper. The second facility, the Commercial Paper Funding Facility (CPFF), buys commercial paper directly from corporations at a term of three months. The Fed announced that the CPFF will purchase up to $\$ 1.8$ trillion over the next several quarters; as of December 31, 2008, the Fed had purchased $\$ 332.4$ billion of commercial paper from companies. The Money Market Investor Funding Facility (MMIFF), announced on October 21, 2008, is the third program implemented by the Fed; this program facilitates the purchase of commercial paper from money market mutual funds directly. These three facilities help to reduce the costs of borrowing for businesses during their daily operations.

\section{No Quick Fix}

In the past year, the Fed has significantly expanded its lending activities by extending the duration, collateral, and scope of its programs. Federal Reserve Chairmen Ben Bernanke noted in his testimony before Congress on November 18 that "credit markets, while still quite strained, are improving. Interbank short-term funding rates have fallen notably since mid-October, and we are seeing greater stability in money market mutual funds and in the commercial paper market." No single facility can provide an instant fix to an ailing economy. Rather, each facility addresses a particular liquidity constraint in the financial markets.

\footnotetext{
${ }^{1}$ See August 10, 2007, Federal Open Market Committee press release.

2 Asset Backed Commercial Paper (ABCP) Money Market Mutual Fund (MMMF) Liquidity Facility; $\underline{\text { AMLF. }}$
} 